\title{
PENGUATAN BRANDING DESA KEPUHSARI MANYARAN WONOGIRI SEBAGAI DESTINASI WISATA KAMPUNG WAYANG TATAH SUNGGING
}

\author{
Ercilia Rini Octavia', Anugrah Irfan Ismail ${ }^{2}$ \\ Jurusan Desain Komunikasi Visual, FSRD, Universitas Sebelas Maret \\ Jl. Ir Sutami No.36A, Jebres, Kec. Jebres, Kota Surakarta \\ Email Korespondensi: erciliaoctavia@gmail.com
}

\begin{abstract}
ABSTRAK
Desa Kepuhsari Kecamatan Manyaran, Kabupaten Wonogiri, Jawa Tengah, sudah sejak lama dikenal sebagai sentra produksi wayang kulit tatah sungging. Hasil tatah sunggingnya terkenal tebal, rapi, dan halus sehingga menjadi salah satu produk unggulan dari Kabupaten Wonogiri. Bahkan, pada tahun 2014 pemerintah telah memberi identitas pada Desa Kepuhsari sebagai 'Kampung Wayang'. Melalui penelitian yang dilakukan dengan pendekatan kualitatif deskriptif, dianalisa dengan metode analisis model interaktif, serta divalidasi dengan triangulasi data ini, mampu menemukenali beberapa potensi di Desa Kepuhsari berupa potensi SDM, alam, wisata budaya dan religi, anyaman bambu, cinderamata, kelompok seni pertunjukan, serta utamanya berupa kerajinan wayang kulit tatah sungging. Kemudian juga menemukan upaya internal yang sudah dilakukan oleh pengelola Kampung Wayang dan pemerintah setempat berupah pembentukan Pokdarwis Tetuko, pengelolaan Kampung Wayang, serta pengembangan industri kreatif untuk perajin wayang tatah sungging. Berdasar temuan data menyoal potensi dan upaya internal tersebut maka dapat dirumuskan beberapa strategi dalam upaya penguatan branding Desa Kepuhsari sebagai Destinasi Wisata Kampung Wayang Tatah Sungging agar keberadaannya tetap eksis dan makin dikenal oleh masyarakat luas baik dalam maupun luar negeri.
\end{abstract}

Kata kunci: industri kreatif, branding, destinasi wisata, kampung wayang, kewirausahaan

\begin{abstract}
Kepuhsari Village of Manyaran Sub District, Wonogiri Regency, Central Java has been long known as wayang kulit tatah sungging production centre. Its tatah sungging product is neat, thick, and fine, thereby becoming one of superior products in Wonogiri Regency. Even in 2014 the government had identified Kepuhsari Village as "Kampung Wayang (Puppet Village). Through research conducted with descriptive qualitative approach, analyzed by interactive model analysis method, and validated by triangulation data, we able to identify some potency in Kepuhsari Village in the form of human resource potential, nature, cultural and religious tourism, woven bamboo, souvenir, performance art, and especially wayang kulit tatah sungging production. Another finding is the internal efforts that have been done by the manager of Wayang Village and the local government in form of Pokdarwis Tetuko, the management of Wayang Village, and the development of creative industries for tatah sungging artists. Based on the findings of the data questioning the potential and internal efforts can be formulated several strategies in efforts to strengthen the branding of Kepuhsari Village as a Tatah Sungging Tourism Village and retain its existence and to be widely known by the public both domestic and foreign.
\end{abstract}

Keywords: creative industry, branding, tourist destination, puppets village, entrepreneurship

PENDAHULUAN 
Wayang kulit merupakan salah satu perwujudan dari kesenian tradisional Indonesia yang tumbuh dan berkembang di kalangan masyarakat Jawa dan Bali. Asal mula kesenian wayang kulit, tidak lepas dari sejarah wayang itu sendiri. Wayang berasal dari sebuah kalimat yang berbunyi "Ma Hyang" yang berarti berjalan menuju yang maha tinggi (yang bisa diartikan sebagai roh, Tuhan Yang Maha Esa, maupun Dewa). Namun, sebagian orang mengartikan wayang berasal dari bahasa Jawa yang memiliki arti: 'bayangan'. Hal tersebut dikarenakan ketika penonton menyaksikan pertunjukan wayang, mereka hanya melihat bayangan yang digerakkan oleh para dalang. Dalang sendiri merupakan singkatan dari kata-kata ngudhal piwulang (Jawa). Ngudhal berarti menyebarluaskan atau membuka dan piwulang berarti pendidikan atau ilmu, dapat diartikan, dalang sebagai orang yang mempunyai ilmu yang 'lebih' serta membagikannya kepada para penonton yang menyaksikan pertunjukan wayang tersebut (http://www.infoyunik.com/2015/09/sejarah-asal-mula-kesenian-wayang-kulit.html).

Sehingga melalui peran dalang, pertunjukan wayang yang biasa kita jumpai dapat digunakan sebagai media untuk menyebarkan ilmu pengetahuan hingga pola tata perilaku yang baik menurut konstruksi sosial yang berlaku di masyarakat Jawa. Begitu sarat akan makna tersebutlah yang menjadikan pertunjukan seni wayang, terutama wayang kulit, bukan hanya sebagai warisan budaya yang luhur bagi bangsa Indonesia, namun telah mendapatkan pengakuan dunia. Tepat pada tanggal 7 November 2003, UNESCO sebagai lembaga yang membawahi kebudayaan dari Perserikatan Bangsa-Bangsa (PBB), menetapkan wayang kulit sebagai wujud seni pertunjukan bayangan boneka dari Indonesia, warisan mahakarya dunia yang tidak ternilai dalam seni bertutur (Masterpiece of Oral and Intangible Heritage of Humanity).

Wayang kulit sebagai mahakarya Indonesia menjadi spesial bukan hanya karena saat dipertunjukkan dibawakan oleh dalang dengan gaya tutur dan keunikan tersendiri sebagai ciri khas penyampaiannya. Namun, juga terletak pada teknik yang digunakan saat proses pembuatannya yang memerlukan keahlian khusus, ketekunan, kesabaran, keuletan, dan rasa kecintaan yang tinggi terhadap cerita pewayangan, yakni dengan teknik 'tatah sungging'. Sesuai dengan namanya, seni tatah sungging merupakan dua kegiatan yang terdiri dari menatah (memahat) dan menyungging (mewarnai). Meski hanya disebut tatah sungging, pembuatan wayang kulit membutuhkan proses yang cukup panjang. Beberapa tahapan yang dilakukan diantaranya pemilihan bahan baku berupa kulit, pengolahan kulit, penatahan, menyungging, danfinishing. Dari beberapa daerah di Jawa Tengah dan Yogyakarta, terdapat desa yang sebagian besar penduduknya adalah perajin wayang kulit yang senantiasa menggunakan teknik tatah sungging dalam pembuatan wayang kulitnya, yaitu di Desa Kepuhsari Kabupaten Wonogiri. Dalam penelitian Yuselg (2016), dijelaskan bahwa jumlah penduduk di Desa Kepuhsari berkisar 6.000 jiwa, 50 orang diantaranya masih aktif berprofesi sebagai pembuat wayang dari total 450 keluarga yang berprofesi sama, dan yang lainnya hanya menjadikan rumahnya sebagai sanggar atau bengkel pembuatan wayang. Warga Desa Kepuhsari selalu konsisten memilih kulit dan tanduk sapi yang berkualitas sebagai bahan dasar untuk membuat wayang kulit hingga pahatan dan pewarnaannya pun sangat halus. Kualitasnya yang tinggi itulah yang membuat perajin wayang di desa ini selalu mendapat pesanan dari dalang-dalang ternama seperti Ki Anom Suroto, Ki Mantep Sudarsono juga yang lainya. (Retno Lawiyani, 2017). Keberadaan Desa Kepuhsari sebagai sentra produksi wayang kulit berimbas pada perkembangan dan peningkatan ekonomi masyarakatnya dengan basis seni, khasanah budaya Indonesia, termasuk budaya Jawa. Tak khayal hal tersebut menjadi perhatian 
pemerintah setempat hingga pada tahun 2014 Desa Kepuhsari ditetapkan sebagai Destinasi Wisata Kampung Wayang Tatah Sungging.

Penetapan Desa Kepuhsari sebagai Destinasi Wisata Kampung Wayang Tatah Sungging oleh pemerintah Kabupaten Wonogiri tersebut bukan hanya karena masyarakatnya yang masih dominan aktif melakukan kegiatan menatah dan menyungging wayang kulit. Namun, terdapat pula beberapa pertimbangan lainnya, seperti yang dituliskan dalam penelitian Ayuk Ningrum (2017), yakni karena Desa Kepuhsari memiliki potensi dalam pengembangan pariwisata minat khusus seperti keunikan kreasi dalam pembuatan cinderamata dan potensi alam yang dimiliki. Pertimbangan pemerintah setempat untuk menjadikan Desa Kepuhsari sebagai Destinasi Wisata Kampung Wayang sesuai dengan Undang-Undang Republik Indonesia nomor 10 tahun 2009 BAB I Pasal 1 Ayat 6, yang menyebutkan bahwa destinasi pariwisata adalah kawasan geografis yang berada dalam satu atau lebih wilayah administratif yang di dalamnya terdapat daya tarik wisata, fasilitas umum, fasilitas pariwisata, aksesibilitas, serta masyarakat yang saling terkait dan melengkapi terwujudnya kepariwisataan. Oleh sebab itu, diperlukan penelitian ini untuk menemukenali dan mendeskripsikan potensi apa saja yang dimiliki oleh Desa Kepuhsari serta upaya apa saja yang bisa dilakukan untuk memperkuat branding-nya sebagai Destinasi Wisata Kampung Wayang. Harapannya penelitian ini mampu mendukung penguatan branding Desa Kepuhsari sebagai Destinasi Wisata Kampung Wayang hingga berdampak positif pada pemasukan ekonomi penduduk Desa Kepuhsari khususnya dan daerah Kabupaten Wonogiri, Jawa Tengah, pada umumnya.

\section{METODE PENELITIAN}

\section{Paradigma dan Metode Penelitian Kualitatif}

Hal pertama yang dilakukan dalam sebuah penelitian adalah memilih dan menetapkan paradigma penelitian yang dapat dijadikan selama panduan selama proses penelitian. Menurut Guba (1990: 17), menguraikan paradigma sebagai seperangkat kepercayaan yang melandasi tindakan sehari-hari maupun dalam kaitannya dengan pencarian keilmuan. Dengan menetapkan paradigma tersebutlah, seorang peneliti dapat memahami fenomena apa yang akan diteliti, baik berkaitan dengan asumsi bagaimana memandang objek penelitian, dan bagaimana melaksanakan proses penelitian (Creswell, 2009). Berdasarkan atas paradigma dan permasalahan yang dipilih dalam penelitian ini, maka penelitian ini menggunakan pendekatan 'kualitatif deskriptif', yang bersifat fleksibel dan terbuka untuk perubahan dan penyesuaian pada saat penelitian sehingga tidak ada batasan bagi peneliti untuk menemukan hal-hal baru yang terkait dengan topik penelitian (Bungin, 2003: 49).

\section{Teknik Pengumpulan Data}

Teknik pengumpulan data yang digunakan dalam penelitian ini adalah:

a. Wawancara mendalam (In-depth interviewing)

Menurut Moleng, tujuan dari teknik wawancara adalah untuk mengkonstruksi mengenai orang, kejadian, kegiatan, organisasi, perasaan, motivasi, tuntutan, merekonstruksi kejadian yang dialami pada masa lalu serta memproyeksikan hal-hal yang diharapkan untuk dialami di masa yang akan datang (Moleong, 2011). Oleh sebab 
itu untuk memperoleh data dilakukan melalui wawancara dengan Lurah Kepuhsari Bapak Sularjo, A.Md., Pengurus Pokdarwis Tetuka Ibu Retno Lawiyani, serta beberapa pengrajin/masyarakat setempat. Sebagai awalan riset, juga diarahkan oleh Bapak Sekretaris Dinas Kebudayaan, Pariwisata, Pemuda, dan Olah Raga Kabupaten Wonogiri Bapak Fredy Sasono

b. Pengamatan langsung (Direct Observation)

Observasi (Direct Observation)yang dilakukan di Desa Kepuhsari merupakan pengamatan dan pencatatan dengan sitematik fenomena-fenomena yang diteliti.

c. FGD (Focus Group Discussion) diselenggarakan dalam sebuah forum diskusi dengan memilih beberapa informan kunci yang diajak untuk membahas mengenai permasalahan penelitian secara mendalam dengan Pengurus Pokdarwis Tetuko.

d. Dokumen/ Arsip

Data dokumen/ arsip serta stok foto digunakan sebagai data sekunder untuk melengkapi data primer dan sebagai bahan pendukung penelitian.

\section{Teknik Sampling}

Teknik sampling yang digunakan dalam penelitian ini adalah teknik purposive sampling. Teknik purposive sampling (memilih sampel yang dipandang paling mengetahui permasalahan) ini sering disebut sebagai judgemental sampling karena peneliti mempertimbangkan untuk memasukkan unsur-unsur yang dianggap khusus dari suatu populasi tempat peneliti mencari informasi. Sampling yang digunakan juga bersifat snowball effect yaitu mengembangkan informan berdasarkan informasi dari informan sebelumnya (Black and Champion, 1992: 264-265) yang berkaitan dengan potensi dan upaya Desa Kepuhsari sebagai destinasi wisata kampung wayang kulit tatah sungging di Kabupaten Wonogiri.

\section{Metode Analisis Data}

Proses analisis data pada penelitian ini akan dilakukan secara terus menerus dimulai dengan menelaah seluruh data yang tersedia dari berbagai sumber, yaitu dari wawancara, pengamatan yang sudah dituliskan dalam catatan lapangan, dokumen, dan sebagainya sampai dengan penarikan kesimpulan. Didalam melakukan analisis data peneliti mengacu kepada beberapa tahapan yang dijelaskan Miles dan Huberman terdiri dari beberapa tahapan antara lain sebagai berikut: Pengumpulan informasi $\rightarrow$ Reduksi data (data reduction) $\rightarrow$ Penyajian data (data display) $\rightarrow$ penarikan kesimpulan/verifikasi (conclution drawing/verification. Berikut metode analisis data dengan model interaktif ini, dapat dilihat pada gambar skema di bawah ini:

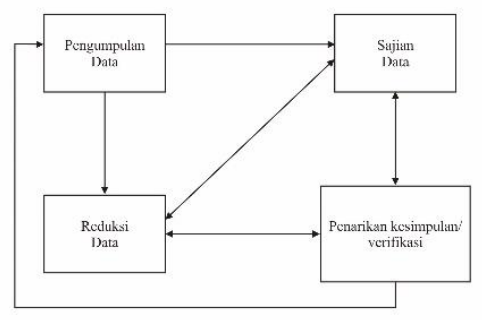

Gambar 1. Metode analisis Model Interaktif (Miles dan Huberman, 2009: 20)

Validitas Data 
Validitas data menggunakan 'triangulasi data', dengan cara mengumpulkan data yang sama dari sumber yang berbeda. Kemudian data yang satu akan dikontrol, di crosscheck, dan dikomparasi oleh data yang sama dari sumber yang berbeda Patton (2002).

\section{Pendekatan Penelitian Tindakan (Action Research)}

Pendekatan penelitian kualitatif deskriptif ini adalah action reseach, yang terdiri dari: siklus diagnosis (masalah), perencanaan tindakan, pelaksanaan tindakan, dan evaluasi tindakan. Terdapat beragam pemikiran mengenai tahapan dan proses action research yang diidentifikasi oleh O'Brien (1998). Data sebagai hasil intervensi dikumpulkan dan dianalisa, dan berbagai penemuannya diinterpretasikan dengan sejauh mana kesuksesan dari tindakan yang telah diimplementasikan. Akhirnya, masalah kembali diukur dan proses ini memulai siklus selanjutnya. Proses ini berlanjut sampai masalahnya dipecahkan (O’Brien, 1998). Berikut bagan siklus action research menurut Rory O'Brien:

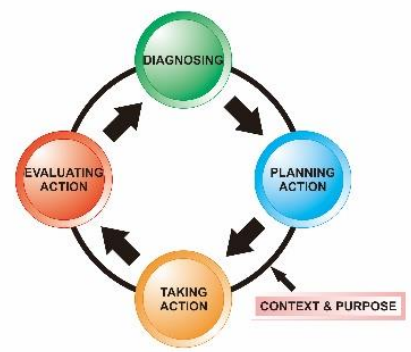

Gambar 2. Proses Siklus Action Research (Rory O’Brien, 1998)

Action Research memiliki tujuan untuk memberikan kontribusi penyelesaian praktis dalam situasi problematis dan membutuhkan alternatif segera serta berdampak sosial lebih luas. Tahap-tahapannya dimulai dari: (1) Diagnosing adalah analisis keadaan saat ini dan mengidentifikasi kebutuhan; (2) Planning Action adalah perencanaan sebagai pengarah; (3) Taking Action adalah perancangan sistem informasi; (4) Evaluating Action adalah peninjauan dengan uji coba. Siklus pada penelitian action research ini, alur operasionalnya disesuaikan dengan konteks dan kegunaannya (O’Brien, 1998).

\section{HASIL DAN PEMBAHASAN}

\section{Desa Kepuhsari Bagian dari Wilayah Kabupaten Wonogiri}

Secara geografis Kabupaten Wonogiri berlokasi di bagian tenggara Provinsi Jawa Tengah. Bagian utara berbatasan dengan Kabupaten Karanganyar dan Kabupaten Sukoharjo, bagian selatan langsung di bibir Pantai Selatan, kemudian di bagian barat berbatasan dengan Gunung Kidul di Provinsi Yogyakarta. Bagian timur berbatasan langsung dengan Provinsi Jawa Timur, yaitu Kabupaten Ponorogo, Kabupaten Magetan dan Kabupaten Pacitan. Kata Wonogiri, dalam bahasa Latin, Wånågiri, secara harfiah berarti 'hutan (di) pegunungan. Kabupaten ini mempunyai luas $1.822,37 \mathrm{~km}^{2}$ dengan populasi 1,5 juta jiwa. 


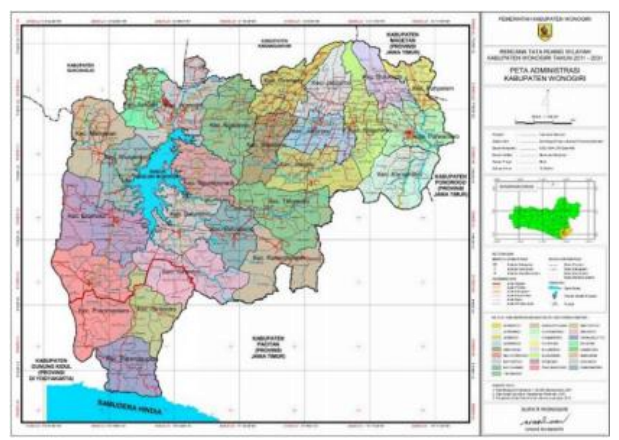

Gambar 3. Peta Kabupaten Wonogiri

(Sumber: Badan Pusat Statistik Kabupaten Wonogiri)

Selama ini, pembangunan yang telah diselenggarakan di Kabupaten Wonogiri menunjukkan kemajuan di berbagai bidang kehidupan masyarakat. Pembangunan tersebut meliputi bidang sosial budaya dan kehidupan beragama, ekonomi, ilmu pengetahuan dan teknologi, sarana prasarana, politik dan tata pemerintahan, keamanan dan ketertiban, hukum dan aparatur, wilayah tata ruang dan pertanahan, sumber daya alam dan lingkungan hidup, serta pariwisata. Salah satu pembangunan daerah di Kabupaten Wonogiri dalam bidang sumber daya alam, lingkungan hidup, dan pariwisatanya adalah Desa Kepuhsari. Desa yang letaknya dekat dengan Waduk Gajah Mungkur ini, berada di bagian selatan Kabupaten Wonogiri, tepatnya di Kecamatan Manyaran. Seperti lazimnya desa-desa lain di Kabupaten Wonogiri yang memiliki tekstur tanah yang kering, tandus, berbatu-batu, dan berbukit-bukit, kondisi alam Desa Kepuhsari pun juga demikian. Tanah yang kering menyebabkan sebagian besar lahan yang digunakan sebagai lahan pertanian kering dengan tanaman ketela pohon mendominasi lahan yang ada. Namun demikian, masyarakat Desa Kepuhsari masih tergantung pada sektor pertanian sebagai sumber mata pencaharian. Kemudian karena letak geografisnya yang hanya mengandalakan musim saja, maka masyarakatnya cenderung menekuni dan melestarikan warisan dari leluhur yaitu membuat wayang kulit tatah sungging. Proses menatah dan menyungging ini sudah mendarah daging bagi penduduk Desa Kepuhsari, khususnya Dusun Kepuh Tengah, dimana hampir setiap rumah memiliki satu anggota keluarga yang memiliki kemampuan menatah wayang kulit. Ketrampilan tersebut sudah menjadi warisan dari leluhur.

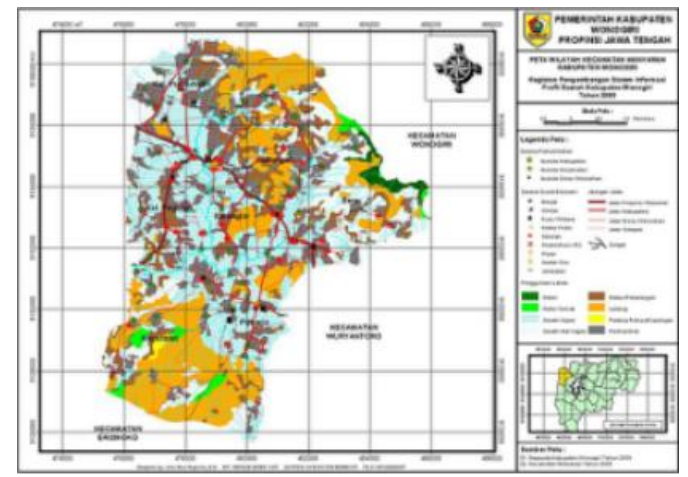

Gambar 4. Peta Desa Kepuhsari

(Sumber: Badan Pusat Statistik Kabupaten Wonogiri)

Berdasar data statistik dari Badan Pusat Statistik (BPS) Kabupaten Wonogiri, Desa Kepuhsari memiliki daerah yang cukup luas yakni 1566,3445 Ha dengan rata-rata curah hujan $343,33 \mathrm{~mm} / \mathrm{dt}$ dan rata-rata hari hujan 9,92 hari/bulan serta tinggi wilayah dari 
permukaan air laut $173 \mathrm{dpl}$. Apabila dilihat dari batas wilayah daerah, maka Desa Kepuhsari terletak diantara beberapa desa. Batas wilayah desa Kepuhsari dengan daerah atau desa lainnya yaitu: sebelah utara berbatasan dengan Desa Karanglo; sebelah selatan berbatasan dengan Desa Ngandong; sebelah timur berbatasan dengan Desa Pijiharto; serta sebelah barat berbatasan dengan Daerah Istimewa Yogyakarta.Untuk mempermudah dalam pelaksanaan pemerintahan, desa ini dibagi menjadi empat belas dusun yaitu: Dusun Kepuhsari, Dusun Kepil, Dusun Tukul, Dusun Garotan, Dusun Ngepringan, Dusun Sambeng, Dusun Duwet, Dusun Kacangan, Dusun Ngluwur, Dusun Lemah Mendak, Dusun Blimbing, Dusun Sendang, Dusun Kadjuman, serta Dusun Karanglo. Desa Kepuhsari sudah memiliki sarana transpontasi yang memadai, berupa jalan yang baik dan alat transportasi yang cukup mudah, yakni dari pusat pemerintahan daerah Wonogiri dapat menggunakan angkutan yang menuju Manyaran. Kemudian, dari kota kecamatan ini naik angkutan sekali lagi menuju Desa Kepuhsari. Atau yang berasal dari luar Wonogiri, bisa menggunakan bus jurusan Praci untuk kemudian turun di Cengkal. Dari Cengkal bisa memilih naik ojek untuk langsung menuju desa, atau naik angkutan umum terlebih dahulu menuju ke Manyaran. Desa ini juga dapat dijangkau melewati Yogyakarta, karena desa ini di sebelah barat berbatasan langsung dengan Daerah Istimewa Yogyakarta.

\section{Sejarah Desa Kepuhsari Sebagai Kampung Wayang}

Keberadaan perajin wayang kulit di Desa Kepuhsari bermula dari peran seorang dalang di desa ini, yaitu Mbah Guno Wasito. Kegiatan Mbah Guno yang berhubungan dengan pementasan wayang kulit tidak hanya sebatas memainkan wayang, akan tetapi juga dalam hal membuat wayang kulit. Mbah Guno menurunkan keahlian mendalang sekaligus membuat wayang kulit kepada kedua anaknya yang bernama Pak Gunarto dan Pak Hadi Carito. Awalnya, keahlian membuat wayang masih milik keluarga ini, selanjutnya Pak Gunarto membuat inisiatif untuk menularkan keahliannya dalam wayang kulit kepada masyarakat sekitar secara gratis. Pak Gunarto memiliki beberapa murid yaitu Pak Sarso, Pak Ngatiman, Mbah Parmo, Pak Katino, dan yang lain-lainnya. Bermula dari murid-murid didikan Mbah Gunarto ini kemudian keahlian pembuatan wayang kulit semakin cepat menyebar ke masyarakat Desa Kepuhsari. Atas inisiatif seorang penduduk yaitu Pak Sukar Hadi Prayitno, para perajin yang telah berkembang jumlahnya ini diajak untuk membuat sebuah perkumpulan perajin wayang kulit yang kemudian berkembang menjadi sebuah koperasi perajin wayang kulit.

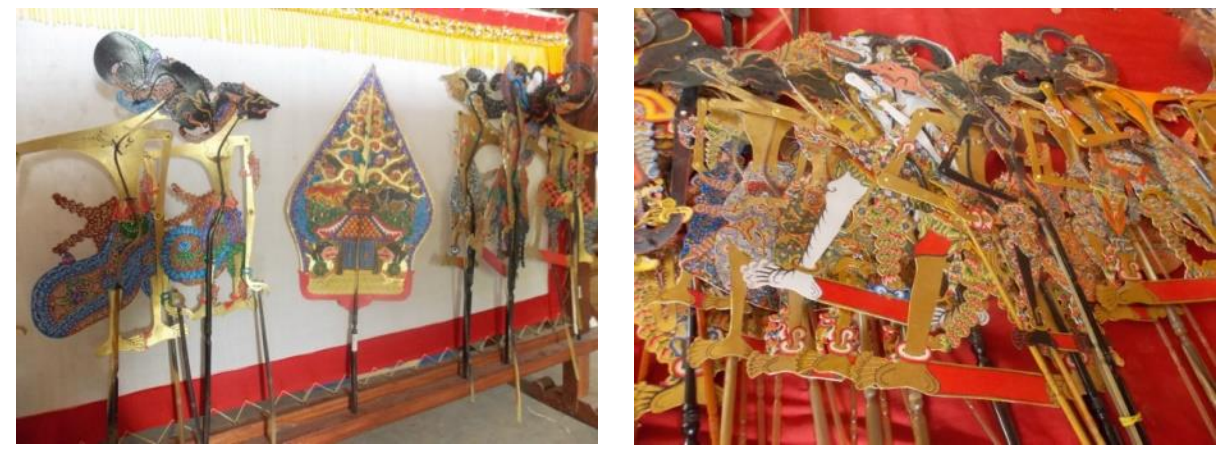

Gambar 5. Hasil produk wayang kulit dari Desa Kepuhsari 
Pendirian koperasi oleh Pak Sukar Hadi Prayitno membuat kerajinan wayang kulit tatah sungging di Desa Kepuhsari semakin maju dan terkenal. Hasil kerajinan wayangnya mampu menembus luar kabupaten, bahkan luar negeri. Selain keberhasilan koperasi, pada saat itu juga mulai tumbuh sanggar wayang yang cukup kuat yaitu sanggar wayang Nimas milik Pak Marso dan sanggar wayang Wagimin. Namun, setelah sepeninggal Pak Sukar Hadi Prayitno sebagai ketua koperasi perajin wayang kulit, terjadi kekacauan manajemen, yang menyebabkan koperasi tidak aktif selama puluhan tahun. Selanjutnya, penerus perajin wayang kulit di Desa Kepuhsari mencoba menghidupkan lagi masa kejayaan itu, penerus tersebut adalah Ibu Retno Lawiyani. Beliau menyadari kalau dirinya dan warga di Desa Kepuhsari punya keistimewaan, khususnya dalam membuat wayang kulit. Beliau memiliki kakek buyut pembuat wayang. Begitu juga dengan suaminya, Bapak Sujoko, yang juga keturunan perajin wayang kulit. Berdasar pengalamannya saat masa kecil dan nama desanya yang tersohor sebagai desa pembuat wayang kulit maka keduanya berusaha menghidupkan kembali Desa Kepuhsari sebagai desa pengrajin wayang kulit tatah sungging. Ibu Retno mengatakan, "beberapa tahun lalu saya belum mempunyai sanggar sendiri untuk menuangkan keahliannya dalam bidang lukis wayang pada media kaca. Begitu juga dengan suami saya yang memiliki keahlian dalam bidang tatah sungging wayang kulit". Berkat ketekunan keluarga ini dalam menggeluti seni lukis kaca dan tatah sungging wayang itu, keluarga Retno akhirnya mampu mendirikan tempat workshop dan membuka sebuah sanggar yang dinamai Asto Kenyo.

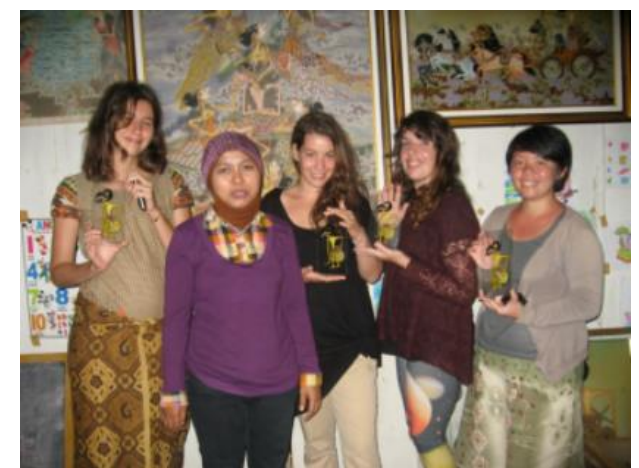

Gambar 6. Kelompok Sadar Wisata (Pokdarwis) Tetuko saat dikunjungi wisatawan asing (Sumber: Dokumentasi Retno Lawiyani)

Sanggar dihidupkan dengan banyak kegiatan, seperti berlatih membuat wayang, bermain gamelan, reog, dan tidak jarang digunakan untuk kursus pelajaran bagi anakanak sekolah. Kemudian, bersama masyarakat desa yang tergugah untuk membangkitkan kampung wayang, mereka mendirikan Kelompok Sadar Wisata (Pokdarwis) Tetuko, pada 2012. Ibu Retno ikut menjadi pengurus Pokdarwis dengan Bapak Giriyanto sebagai ketuanya hingga saat ini (2018). Pokdarwis tersebut menghimpun relawan yang sadar mengembangkan desa wisata, bahkan Ibu Retno merelakan sanggarnya sebagai sekretariat Pokdarwis.Tujuan pokdarwis ini tidak lain adalah untuk memperkuat dan melestarikan kebudayaan Indonesia yang banyak tergantikan oleh budaya lain. Diharapkan dengan adanya pokdarwis di Kampung Wayang Desa Kepuhsari, para pengrajin wayang dapat mengembangkan dan meningkatkan potensi budaya juga menyejahterakaan masyarakatnya secara ekonomi.

Potensi Desa Kepuhsari dalam Mendukung Branding-nya Sebagai Destinasi Wisata Kampung Wayang 
Marc Gobe, dalam bukunya "Emotional Branding", mendefiniskan branding sebagai sebuah penciptaan merek. Secara sederhana, bisa disimpulkan bahwa branding merupakan suatu tindakan untuk memberikan identitas kepemilikan (2010). Sedangkan Goeldner dalam Iliachenko (2005: 4) mendefinisikan destination branding sebagai seperangkat asosiasi merek yang dapat menjadi tanda pengenal atau pembeda suatu lokasi dengan menawarkan pengalaman berwisata yang mengesankan pada lokasi tersebut. Sementara Kaplanidou (2003: 2) mendefinisikan destination branding sebagai kombinasi atribut sebuah daerah yang diwujudkan dalam satu konsep yang dapat menyampaikan identitas unik dan karakteristik lokasi yang berbeda dari kompetitornya. Pemberian identitas unik dan karakteristik lokasi, salah satunya didasarkan atas 'potensi' yang dimiliki oleh tempat/daerah tersebut. Beberapa potensi yang mendukung Branding Desa Kepuhsari sebagai Destinasi Kampung Wayang Tatah Sungging, diantaranya adalah:

a. Potensi Sumber Daya Manusia (SDM)

Berdasar atas Data Monografi Desa Kepuhsari 2016, jumlah penduduk berdasarkan tingkat pendidikan, dapat dilihat pada tabel berikut ini;

Tabel 2. Jumlah Penduduk Desa Kepuhsari Menurut Jenis Pendidikan

\begin{tabular}{|l|l|l|l|}
\hline No & Pendidikan & Jumlah & $\%$ \\
\hline 1. & Tamat Akademi/Perguruan Tinggi & 676 & 11,1 \\
\hline 2. & Tamat SMA & 1.154 & 19 \\
\hline 3. & Tamat SMP & 1.484 & 24,4 \\
\hline 4. & Tamat SD & 1.258 & 20,7 \\
\hline 5. & Tidak Tamat SD & 368 & 6 \\
\hline 6. & Belum Tamat SD & 522 & 8,6 \\
\hline 7. & Tidak Sekolah & 623 & 10,2 \\
\hline \multicolumn{2}{|r}{ Jumlah } & 6.085 & 100 \\
\hline
\end{tabular}

(Sumber: Data Monografi Desa Kepuhsari 2016)

Struktur sosial ekonomi masyarakat desa Kepuhsari didominasi oleh penduduk dengan tingkat pendidikan mayoritas lulusan SD dengan prosentase $24,4 \%$ yaitu sebanyak 1.258 jiwa dan SMP dengan prosentase 20,7\% yaitu sebanyak 1.484 jiwa. Berdasar tabel tersebut terlihat perbandingan yang melanjutkan pendidikan sampai perguruan tinggi lebih banyak dibandingkan yang tidak atau belum sekolah. Hal ini menunjukkan bahwa penduduk Desa Kepuhsari mulai memiliki kesadaran untuk memperoleh pendidikan yang lebih tinggi. Masyarakat dengan pendidikan tinggi berpotensi untuk meningkatkan pemberdayaan Desa Kepuhsari dalam mewujudkannya sebagai Destinasi Wisata Kampung Wayang Tatah Sungging.

b. Potensi Alam

Desa Kepuhsari merupakan salah satu daerah tujuan wisata di Kabupaten Wonogiri yang cukup potensial karena selain memiliki keunikan budaya, juga memiliki panorama alam, dan potensi obyek wisata yang menarik serta dapat menjadi sarana edukatif bagi wisatawan. Sumber daya potensial wisata alam Desa Kepuhsari adalah Wonogiri sebagai berikut:

1) Umbul Naga Karanglor

Umbul Naga Karanglor merupakan sumber mata air alam yang ada di Dusun Karanglo Desa Kepuhsari. Lokasi ini memiliki luas sekitar dua hektare yang terdapat tiga kolam. Kolam yang letaknya paling atas merupakan umbul atau sumber air utama. Sedangkan di bagian bawah terdapat dua kolam, salah satunya untuk pembenihan ikan air tawar. Sedangkan kolam bagian bawah yang merupakan pecahan sumber air dari umbul utama, terdapat hewan langka yang disebut 
masyarakat setempat sebagai Gateng atau Sidat. Hewan itu berbentuk seperti belut, tetapi bertaring dan memiliki sirip seperti ikan lele. Setiap bulan, ikan betina menstruasi layaknya seorang perempuan sehingga saat itu air tempat mereka hidup berubah menjadi merah.
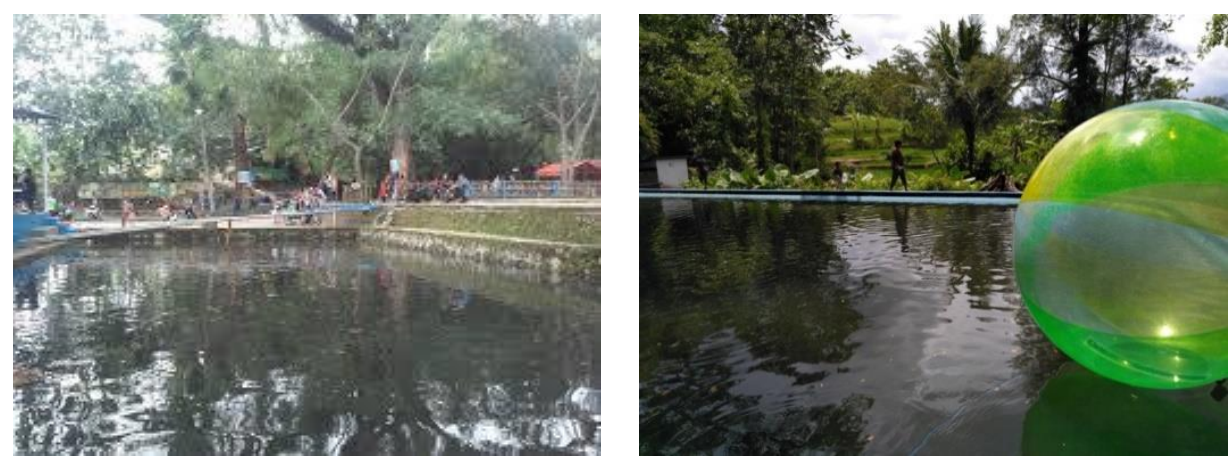

Gambar 7. Umbul Naga Karanglor Desa Kepuhsari

(Sumber: http://www.solopos.com/2017/02/01/wisata-wonogiri-pengelola-akan-bangunwaterboom-di-umbul-nogo-manyaran-789339)

2) Air Terjun Banyu Nibo

"Banyu Nibo", berarti air yang jatuh dari ketinggian, ketinggiannya sekitar 50 meter dan langsung jatuh mengenai batu besar yang berada di bawahnya. Airnya yang mengalir langsung mengairi sawah-sawah masyarakat Desa Kepuhsari.
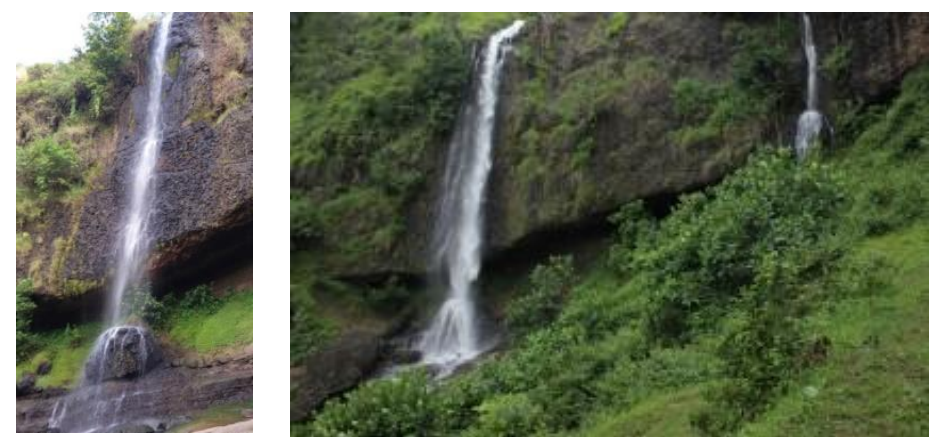

Gambar 8. Air Terjun Banyu Nibo Desa Kepuhsari

(Sumber: https://threexplorer.blogspot.co.id/2016/06/air-terjun-yang-cantik-dan-perawanair.html)

3) Gunung Panggung

Pegunungannya ini terdiri dari batu-batu hitam menyerupai gunung api purba, kemudian terdapat empat air mancur, diantaranya yang paling besar adalah Air Terjun Banyu Nibo. 

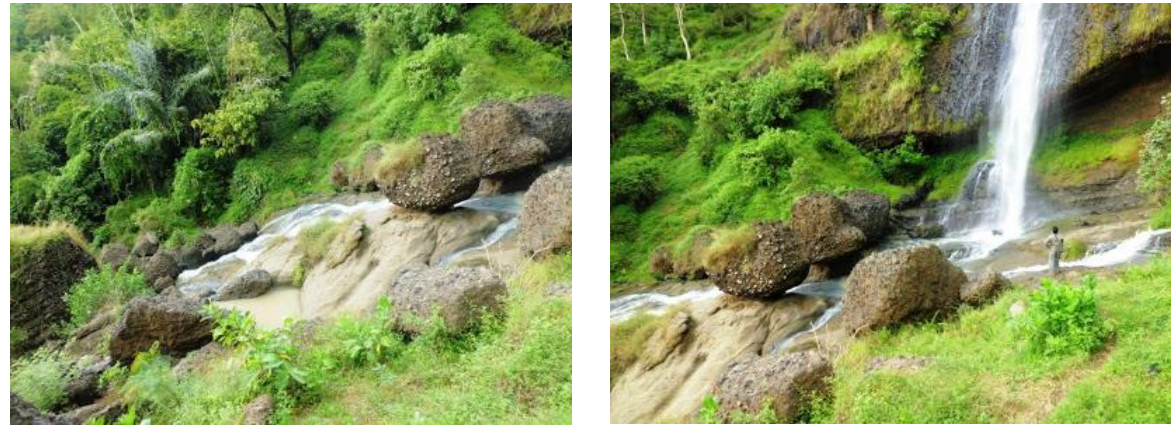

Gambar 9. Gunung Panggung Desa Kepuhsari

(Sumber: http://cahyaniekaromadhoni.blogspot.co.id/2013/05/air-terjun-banyu-nibo-si-cantikyang.html)

4) Kampung Batu, terdapat di Kepuhsari, Manyaran, Wonogiri dimana suatu daerah dikelilingi oleh tebing-tebing dan di tengahnya ada suatu perkampungan kecil. Jika dilihat dari atas tebing akan terlihat sangat indah.

5) Gunung Kotak

Disebut sebagai Gunung Kotak karena bentuknya yang menyerupai kotak atau persegi dalam bahasa Indonesia, kemudian bebatuannya berbentuk mirip lesung. Gunung ini terletak di Kepuhsari, Manyaran, Wonogiri.

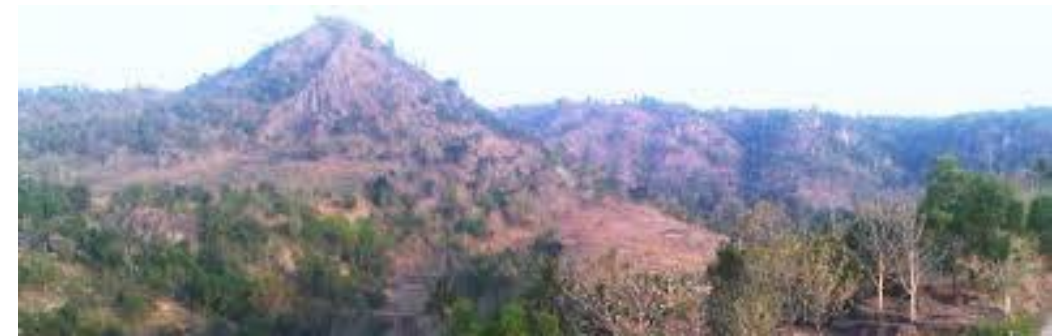

Gambar 10. Gunung Kotak Desa Kepuhsari

(Sumber: http://cahyaniekaromadhoni.blogspot.co.id/2013/05/air-terjun-banyu-nibo-si-cantikyang.html)

c. Potensi Wisata Budaya dan Religi

1) Masjid Tiban

Masjid ini merupakan peninggalan sejarah, dimana tidak ada yang tahu tahun berapa masjid ini dibangun dan oleh siapa yang membangunnya. Masjid Tiban ini merupakan cagar budaya yang harus dilestarikan oleh semua pihak.
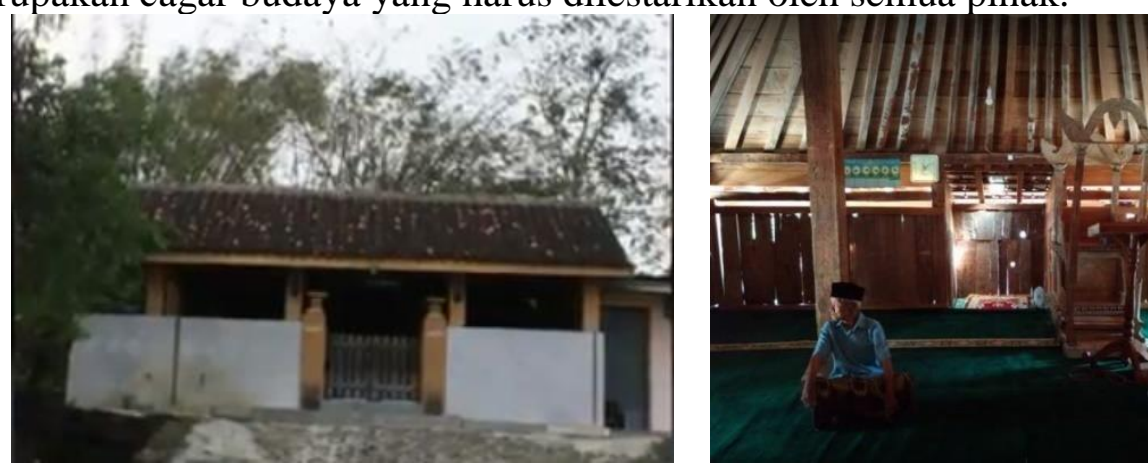

Gambar 11. Masjid/Langgar Tiban Desa Kepuhsari 


\section{2) Gong Kyai Selamet}

Gong merupakan alat musik tradisional Jawa yang sering digunakan untuk mengiringi nyanyian tradisional atau orkes Jawa agar alunan musik menjadi indah dan enak didengar. Akan tetapi Gong Kyai Slamet yang berada di Desa Kepuhsari ini dijadikan gong keramat dan hanya dikeluarkan satu tahun sekali yaitu pada 1 Syawal. Mengeluarkan gong ini pun harus digendong oleh orang yang dilegaaken (diperbolehkan). Ketika Gong ini dikeluarkan ada perayaan berupa tari-tarian sehingga banyak masyarakat yang menyaksikannya. Gong Kyai Slamet dipercaya sebagai pondasi wilayah Desa Kepuhsari, Manyaran, Wonogiri.

\section{d. Potensi Anyaman Bambu}

Kerajinan anyaman bambu diDesa Kepuhsari berupa berbagai bentuk kerajinan anyaman seperti bakul, tempat pencil, dan berbagai hasil anyaman lainnya.

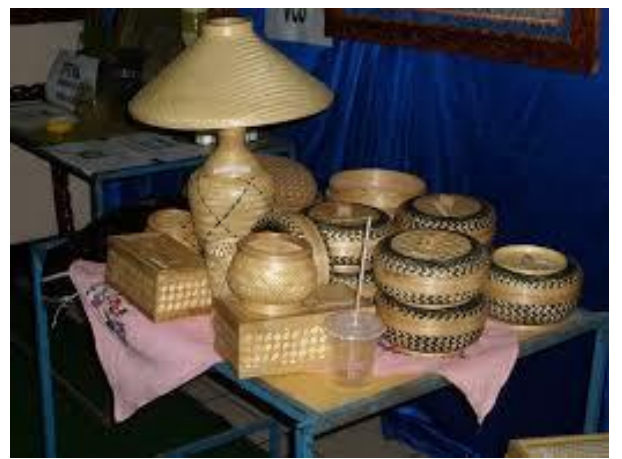

Gambar 11. Hasil Ayaman Bambu Desa Kepuhsari

e. Potensi Cinderamata

Selain kerajian anyaman, masyarakat Desa Kepuhsari juga membuat berbagai cinderamata yang berbahan dasar kulit sapi/kerbau. Cinderamata tersebut berupa gantungan kunci, pembatas buku, souvenir untuk pengantin, dan lain-lain.

f. Potensi Kelompok Seni Pertunjukan seperti Angklung dan Reog
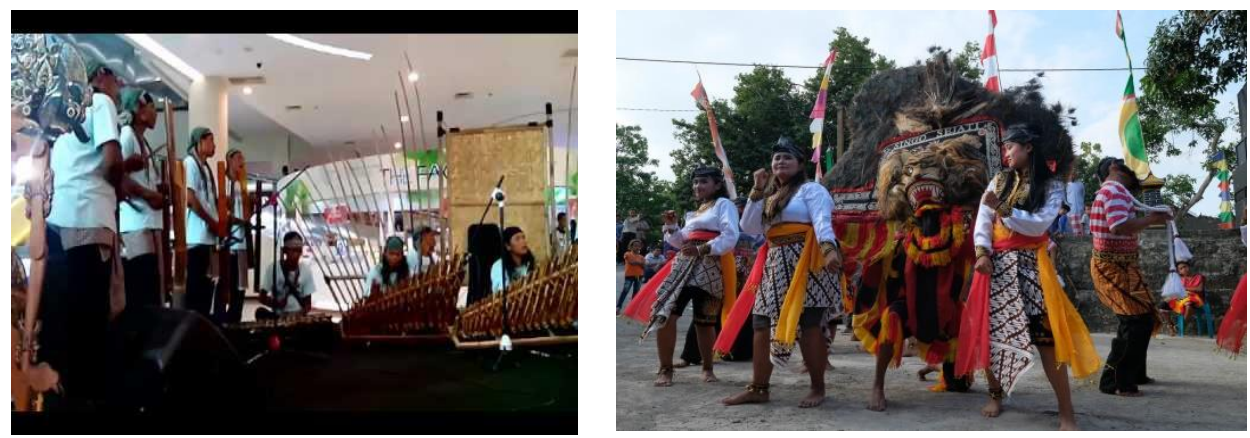

Gambar 12. Pertunjukan Musik Angklung dan Reog Desa Kepuhsari

\section{g. Potensi Kerajinan Wayang Kulit Tatah Sungging}

Tatah sungging Desa Kepuhsari yang merupakan industri kerajinan kulit ini merupakan potensi unggulan bagi Kabupaten Wonogiri. Di Desa Kepuhsari terdapat perajin wayang kulit yang berjumlah lebih dari seratus orang, hanya sifat dari perajin ada yang sebagai mata pencaharian pokok dan sambilan, serta ada aturan yang 
mengikat bahwa tiap perajin harus ikut kelompok perajin wayang, sehingga tidak ada catatan yang menyebutkan jumlah perajin secara pasti. Dalam pengerjaannya mereka bekerja sendiri atau tidak mempunyai tenaga, bagi perajin kecil bergabung dengan perajin yang lebih besar atau perajin yang sudah mempunyai sanggar. Kegiatan pembuatan kerajinan wayang kulit ini melalui beberapa tahap:

1) Mencari bahan baku kulit kerbau. Dalam tahap ini biasanya perajin telah mempunyai tempat berlangganan sendiri.

2) Mengerok yaitu proses menghilangkan bulu dan kotoran yang terbawa dalam kulit.

3) Corek yaitu membuat sketsa wayang di atas kulit yang telah siap ditatah.

4) Tatah yaitu proses membuat ukiran pada kulit yang telah dicorek terlebih dahulu. Proses ini adalah proses yang tersulit dan membutuhkan ketelitian dan kesabaran, karena kualitas wayang tergantung pada kualitas tatahannya.

5) Sungging adalah proses memberi warna pada wayang yang telah ditatah. Corak warna pada wayang kulit terus berubah mengikuti perkembangan.

6) Pemasangan Cempurit adalah pemberian gagang pada wayang yang terbuat dari tanduk kerbau.
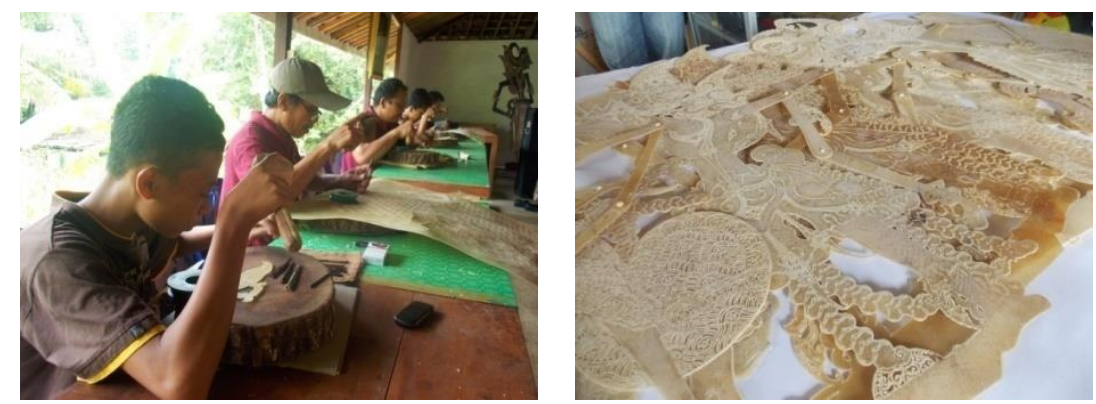

Gambar 13. Proses tatah sungging dan hasilnya oleh Perajin Wayang Kulit di Desa Kepuhsari

Dalam proses pembuatan wayang kulit ini ada pembagian tugas atau pembagian kerja berdasarkan tahap-tahap pembuatan wayang seperti tersebut di atas. Biasanya di setiap sanggar wayang ada pembagian proses kerja menurut tahapan-tahapannya. Untuk mencari bahan baku biasanya ditangani langsung oleh pemilik sanggar. Kulit yang dibeli ini kemudian diserahkan kepada tukang kerok yang ada di desa ini. Setelah kulit siap dipakai oleh pemilik sanggar akan dicorek atau digambar sesuai dengan pesanan. Kulit yang telah dicorek ini kemudian diberikan kepada penatah. Beberapa penatah sungging yang ada di sanggar, jika dalam pengerjaannya tidak selesai, maka sebagian ada yang membawa pulang pekerjaan mereka untuk dilanjutkan di rumah. Selain faktor keberadaan seniman wayang kulit yang lebih lama dan jumlah perajin yang lebih banyak, terbukti bahwa kegiatan ini telah ikut membantu kehidupan para perajin. Kebiasaan seperti ini semakin memperkuat citra Desa Kepuhsari sebagai kampung wayang (Andreas S Widodo, 2016).

\section{Upaya Branding Desa Kepuhsari Sebagai Destinasi Wisata Kampung Wayang}


Perkembangan trend wisata global, yang mengarah pada eko wisata, wisata budaya dan wisata pendidikan (dimana wisatawan tidak hanya melihat, namun berusaha menyatu, menyelami dan bahkan sebagai pelaku seni budaya masyarakat yang dikunjungi), hal ini ditangkap oleh pelaku-pelaku seni tatah sungging di Desa Kepuhsari sebagai peluang. Selain menjual produk wayang dengan berbagai variasinya, juga menjual bagaimana cara membuat wayang dan mengajak tamu berperan langsung dalam pagelaran wayang kulit. Selain itu wisatawan diajak melihat secara langsung kehidupan sosial ekonomi masyarakat pengrajin tatah sungging. Oleh sabab itulah, pemerintah setempat menetapkan branding Desa Kepuhsari sebagai Destinasi Wisata Kampung Wayang Tatah Sungging. Beberapa program wujud 'upaya internal' yang ditemukan di Desa Kepuhsari untuk mendukung penetapan branding-nya sebagai Destinasi Wisata Kampung Wayang adalah:

a. Pembentukan Kelompok Sadar Wisata (Pokdarwis) Tetuko

Maksud dari Kelompok Sadar Wisata Tetuko dalam pembentukan Kampung Wayang sebagai pengembangkan Desa Wisata yaitu untuk meningkatkan sumberdaya manusia dalam hal seni tatah sungging wayang di Desa Kepuhsari, menyediakan paket-paket wisata yang berbasis seni tatah sungging dengan segala nilai historis, filosofis, sosiologis dan ekonomi serta sektor pendukung baik sebagai produk, maupun tata cara pembuatannya serta nilai sosial budaya yang menjadi latar belakang berkembangnya budaya tatah sungging tersebut. Adapun tujuan dari Kelompok Sadar Wisata dalam pembentukan Kampung Wayang yaitu: 1) Melestarikan nilai-nilai luhur seni budaya tatah sungging; 2) Meningkatkan nilai ekonomi seni budaya tatah sungging; 3) Mengembangkan obyek-obyek wisata pendukung; serta 4) Mengintergrasikan pengembangan berbagai sektor ekonomi masyarakat. Pengelolaan Pokdarwis Tetuko, sebagai berikut; 1) Pelindung : Sularjo (Kepala Desa); 2) Ketua : Giriyanto; 3) Sekretaris : Triyatmoko; 4) Bendahara : Retno Lawiyani; serta 10 seksi yang membidangi beberapa segi kepengurusan Pokdarwis Tetuko

b. Pengelolaan Desa Kepuhsari sebagai Kampung Wayang.

1) Pembentukan Homestay.

Homestay diperuntukan bagi wisatawan domestik dan mancanegara atau bahkan peneliti yang ingin mempelajari lebih lanjut tentang potensi Desa Kepuhsari, terutama menyoal wayang kulit tatah sungging. Melalui pembentukan homestay ini melatih masyarakat untuk lebih mandiri dalam mendapatkan penghasilan dan sarana untuk memperoleh pengetahuan.

2) Regenerasi Pengrajin Wayang dan Pengelola Kampung Wayang.

Pokdarwis Tetuko yang berusaha memberdayakan kaum muda sebagai generasi penerus baik kelak sebagai pengrajin maupun pengelola Kampung Wayang. Hal ini mempunyai tujuan agar kaum muda lebih berpikiran maju dan dapat mengikuti perkembangan jaman sehingga diharapkan dengan mengikutkan kaum muda dalam pengelolaan Pokdarwis Tetuko, dapat mengembangkan Desa Kepuhsari sebagai Kampung Wayang yang lebih baik dan maju. Sealin itu, tatah sungging juga dimasukkan ke dalam kurikulum mata kuliah SD dan SMP yang ada di Kepuhsari, agar mereka dapat meneruskan seni tatah sungging dan menjaga eksistensinya.

3) Pengelolaan Kegiatan yang Dilakukan oleh Pokdarwis Tetuko. 
a) Perencanaan kegiatan melalui rapat rutin yang diadakan, untuk membahas apa saja yang akan dilakukan. Kemudian menyusunnya dalam agenda fix agar dapat direalisasikan sebagai agar Kampung Wayang lebih maju.

b) Menyelenggarakan paket-paket wisata Kampung Wayang dengan konsep full day tour. Paket-paket wisata memungkinkan interaksi wisatawan secara langsung dengan pelaku tatah sungging, pada satu sisi merupakan media untuk menyebarkan kemampuan membuat wayang, namun disisi lain merupakan upaya untuk menyebarluaskan budaya wayang, sehingga nantinya wayang akan tetap eksis.

c) Evaluasi rutin setelah pelaksanaan kegiatan selesai

c. Pengembangan Industri Kreatif untuk Pengrajin.

1) Perkumpulan Pokdarwis Tetuko

Merupakan media untuk bertukar informasi dan pengetahuan, tukar pendapat mengenai pembuatan wayang kulit, berdiskusi mengenai kegiatan yang akan dan sudah dilakukan terkait dengan pengembangan kampung wayang.

2) Pelatihan Lukis Kaca.

Pelatihan ini berfungsi untuk menambah ketrampilan serta memenuhi tanggungjawab pengrajin sebagai trainer dalam paket-paket wisata Kampung Wayang. Mengingat paket wisata tidak hanya memfasilitasi pengunjung untuk pelatihan tatah sungging saja tetapi juga pelatihan lukis kaca.

3) Pelatihan Pengembangan Produk

Kegiatan dalam pelatihan pengembangan produk meliputi pengolahan sisa bahan baku kulit yang tidak terpakai agar menjadi produk bernilai jual, seperti souvenir (hiasan dinding wayang dalam pigura, gantungan kunci, miniatur wayang, kipas, hiasan pinsil hingga sampul buku). Bahkan pengembangan produk ini membawa Desa Kepuhsari sebagai pembuat Souvenir Maskot Asean Game 2018.
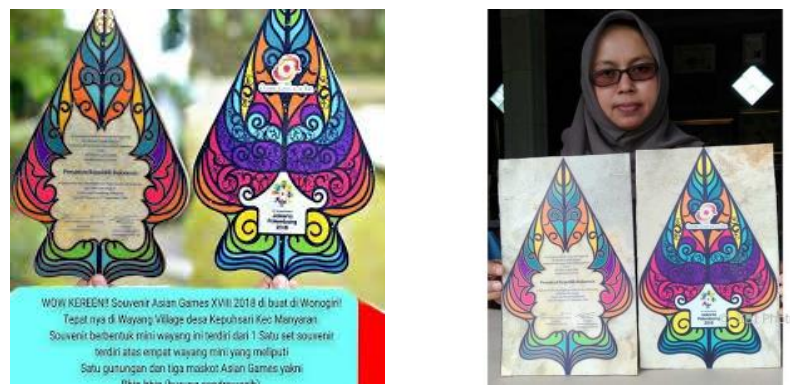

Gambar 14. Retno Lawiyani Pembuat Souvenir Maskot Asean Game 2018 (Sumber: https://www.timlo.net/baca/68719751900/pengrajin-asal-wonogiri-dapatorder-buat-cinderamata-asian-games/)

4) Pelatihan Berbahasa Inggris.

Pelatihan berbahsa Inggris penting bagi semua pengrajin yang bertanggungjawab sebagai guide maupun trainer, karena secara langsung akan berkomunikasi dengan wisatawan mancanegara. 


\section{Penguatan Branding Desa Kepuhsari Manyaran Wonogiri Sebagai Destinasi Wisata Kampung Wayang}

Program wujud'upaya internal' yang ditemukan di Desa Kepuhsari untuk mendukung penetapan branding-nyasebagai Destinasi Wisata Kampung Wayang telah membantu mewujudkan pengembangan "Kampung Wayang" yang tidak terlepas dari konsep pengembangan desa wisata, dimana dua komponen utama desa wisata harus terpenuhi, yaitu adanya atraksi dan penyediaan akomodasi, dengan kata lain konsep pengembangan desa wisata harus memenuhi syarat apa yang bisa dilihat, apa yang bisa dikerjakan dan apa yang bisa dibeli di daerah tujuan wisata. Apa yang bisa dilihat merujuk pada atraksi wisata yang menjadi obyek, yang utamanya adalah seni tatah sungging beserta karakteristik sosial ekonomi dan ciri khas masyarakatnya, dengan tetap mempertahankan kondisi keasliannya. Namun, tetap diperlukan beberapa strategi dalam upaya penguatan branding Desa Kepuhsari sebagai Destinasi Wisata Kampung Wayang Tatah Sungging agar keberadaannya tetap eksis dan makin dikenal oleh masyarakat luas baik dalam maupun luar negeri. Morgan dan Pritchard (dalam Murfianti, 2010), menyarankan lima tahapan untuk melakukan destination branding dalam menguatkan sebuah image daerah yaitu: a. Market investigation, analysis and strategic recommendations; b. Brand identity development; c. Brand launch and introduction, communicating the vision; d. Brand implementation; serta e. Monitoring, evaluation, and review.

Beberapa tahap penguatan Branding Desa Kepuhsari Manyaran Wonogiri Sebagai Destinasi Wisata Kampung Wayang, adalah sebagai berikut:

a. Market investigation, analysis and strategic recommendations

Pada tahap awal ini, Pokdarwis Tetuko dan pemerintah setempat sudah melakukan analisis mengenai potensi Desa Kepuhsari. Potensi tersebut terdiri dari potensi Sumber Daya Manusia, potensi alam (Umbul Naga Karanglor, Air Terjun Banyu Nibo, Gunung Panggung, Kampung Batu, Gunung Kotak), potensi wisata budaya dan religi (Masjid Tiban dan Gong Kyai Selamet), potensi anyaman bambu, potensi cinderamata, potensi Kelompok Seni Pertunjukan seperti Angklung dan Reog, serta potensi kerajinan wayang kulit tatah sungging sebagai potensi unggulan. Kemudian dengan mengajak masyarakat lainnya, pengelola Pokdarwis Tetuko dan pemerintah setempat mulai merancang strategi untuk engembangkan Desa Kepuhsari menjadi Kampung Wayang. Tahap berikutnya adalah mengupayakan agar potensi tersebut berdaya guna menguatkan branding Kampung Wayang. Hal ini menunjukkan bahwa Pokdarwis Tetuko, pemerintah setempat, beserta masyarakat telah melakukan fungsi darimarket investigation, analysis and strategic recommendations.

\section{b. Brand identity development}

Pembentukan brand identity Desa Kepuhsari didasarkan pada visi, misi, dan image yang ingin dibentuk. Visinya berupa pemberdayaan Sumber Daya Manusia Desa Kepuhsari dalam mempertahankan eksistensi pembuatan wayang kulit tatah sungging dengan memahami dan memaknai nilai-nilai historis, filosopis dan sosiologis yang terkandung didalamnya. Misinya agar dapat: 1) Melestarikan nilai-nilai luhur seni budaya tatah sungging; 2) Meningkatkan nilai ekonomi seni budaya tatah sungging; 3) Mengembangkan obyek-obyek wisata pendukung; serta 4) Mengintergrasikan 
pengembangan berbagai sektor ekonomi masyarakat. Untuk mewujudkan visi misi maka image sebagai Kampung Wayang mulai dicanangkan di Desa Kepuhsari. Konsep ini menunjukkan bahwa tahap brand identity development merupakan tahap menentukan identitas daerah yang bersifat intagible yang diperkenalkan kepada publik, untuk menggambarkan Desa Kepuhsari. Namun, saat ini Desa Kepuhsari sebagai Destinasi Wisata Kampung Wayang Tatah Sungging sudah memiliki logo yang konsisten karena logo adalah identitas dari sebuah korporat. Logo akan merepresentasikan visi, misi, serta prestise dari sebuat korporat.

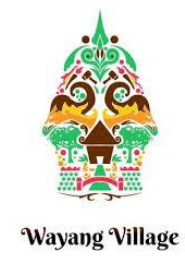

Gambar 15. Logo Kampung Wayang Desa Kepuhsari

Namun tagline dari Kampung Wayang belom diciptakan. Melalui tagline/slogan, pengunjung akan selalu mengingat Desa Kepuhsari sebagai Kampung Wayang. Tahap pengembangan brand identity ini dapat dilakukan melalui forum Focus Group Discussion (FGD) dengan pemerintah setempat, stakeholderdan para akademisi perguruan tinggi terkait untuk menemukan strategi brand identitylebih lanjut agar brandingDesa Kepuhsari sebagai Destinasi Wisata Kampung Wayang semakin kuat.
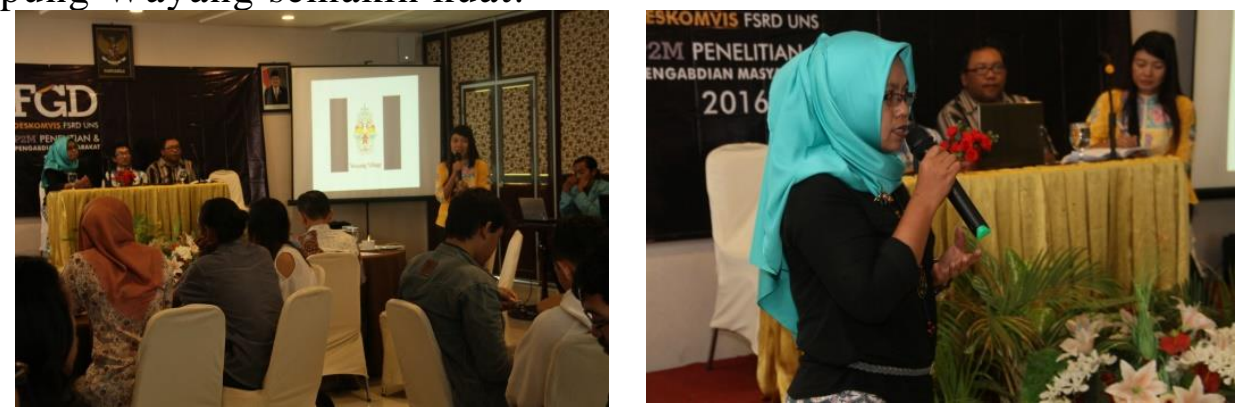

Gambar 16. FGD Strategi Branding Desa Kepuhsari Sebagai Destinasi Wisata Kampung Wayang, Retno Lawiyani dengan Peneliti, Stakeholder, dan Mahasiswa UNS

\section{c. Brand launch and introduction, communicating the vision}

Setelah logo maupun tagline/slogan dibuat, tahap berikutnya adalah memperkenalkan brandmelalui berbagai media. Beberapa media yang sudah dibuat untuk mengomunikasikan keberadaan Desa Kepuhsari sebagai Destinasi Wisata Kampung Wayang adalah brosur, baliho, serta website www.wayangvillage.com dan www.astokenyo.com . Namun, sayangnya pengimplementasian brosur dan baliho tidak memvisualisasikan karakter tone and manner yang sama sebagai strategi komunikasi penciri dari branding Desa Kepuhsari sebagai Destinasi Wisata Kampung Wayang. Baik dari logo yang dicantumkan, maupun konsistensi warna yang diterapkan. Padahal dalam setiap pengaplikasian brand identity harus tetap mempertimbangkan konsistensi kunci visual sebagai perwakilan karakter dari Kampung wayang, mulai dari dari pemilihan layout/tata letak, ilustrasi, warna, tipografi hingga tekstur yang menjadi materi dalam media tersusun secara seimbang 
dan menyatu, sehingga mampu menyampaikan pesan tentang eksistensi Kampung Wayang kepada pengunjung sebagai target audience-nya. Kemudian website yang sudah dibuat, tidak aktif lagi. Sebenernya selain untuk memberikan gambaran mengenai atraksi, akomodasi serta produk apa saja yang ditawarkan di Kampung Wayang, melalui website dapat digunakan sebagai media komunikasi dan interaktif yang terjadi antara pengelola Pokdarwis Tetuko dengan pengunjung/calon pengunjung.
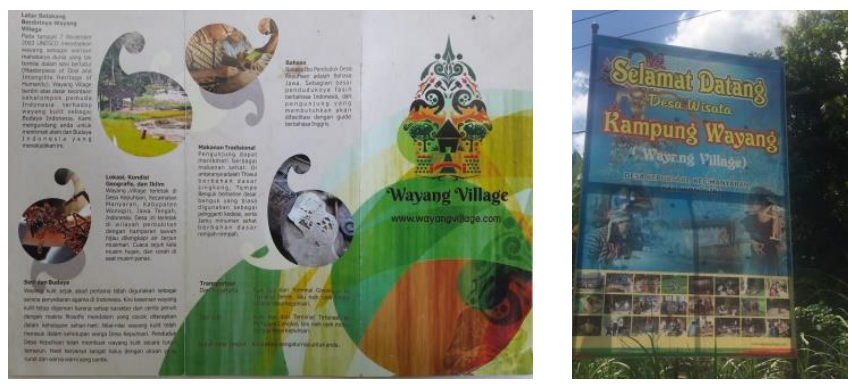

Gambar 17. Brosur dan baliho Kampung Wayang Desa Kepuhsari

\section{d. Brand implementation}

Tahap selanjutnya, untuk semakin memperkuat brand Desa Kepuhsari sebagai Destinasi Wisata Kampung Wayang adalah dengan mensosialisasikan tagline/slogan baru yang kan dibuat, sehingga masyarakat Desa Kepuhsari dapat merealisasikan tagline/slogan sebagi falsafah dalam kehidupan sehari-hari. Selain itu, masyarakat juga diedukasi mengenai karakter visual yang dipakai untuk merepresentasikan maksud, tujuan, dan pesan yang ingin disampaikan melalui bernbagai media komunikasi. Hal ini sesuai dengan tahap brandimplementation yang merupakan suatu usaha untuk mengintegrasikan semua pihak yang terlibat dalam pembentukan brand, sehingga destination branding sebagai Kampung Wayang dapat berhasil. Pengimplementasian logo, tagline serta identitas brand dapat dilakukan melalui beberapa media seperti:

1) Stationary, merupakan perlengkapan kantor yang digunakan untuk keperluan surat menyurat seperti amplop, kertas surat, dan map. Serta beberapa material brand seperti kartu nama, nota, kuitansi pemesanan, daftar paket wisata.

2) Baliho/ billboard, yang berisi potensi wisata Desa Kepuhsari sebagai Kampung Wayang, atau agenda wisata Desa Kepuhsari atau bahkan bisa juga berisi peta wisata Desa Kepuhsari. Dapat dipasangkan di tempat strategis sebelum masuk kawasan Desa Kepuhsari atau dekat area pemerintah daerah Kabupaten Wonogiri.

3) Spanduk, yang berisi tentang informasi event atau atraksi yang akan diselenggarakan dalam waktu dekat.

4) Umbul-umbul, dipasangkan pada jalan menuju Desa Kepuhsari.

5) Traffic ad, digunakan sebagai penunjuk jalan. Sehingga memberikan akses yang mudah bagi pengunjung untuk dapat menjangkau area Kampung Wayang.

6) Name board/ neon box sebagai pemberi tanda identitas Kampung Wayang; untuk sekretariat Pokdarwis Tetuko; sanggar-sanggar pengrajin wayang tatah sungging; untuk penamaam homestay serta tempat-tempat tertentu yang termasuk dalam sajian paket-paket wisata Kampung Wayang.

7) Pembuatan buku ilustrasi yang berisi tentang tokoh-tokoh dalam pewayangan sehingga dapat digunakan pengrajin sebagai media pembelajaran mengenai makna 
filosafis dan historis tokoh serta cerita pewayangan. Hal ini sangat bermanfaat apabila pengrajin menjadi trainermaupun tourguide.

8) Pembuatan buku coffee table book. Melalui coffee table book, calon pengunjung mengetahui segala sesuatu tentang Kampung Wayang ini sehingga secara langsung mampu dijadikan sebagai media promosi Desa Kepuhsari sebagai Kampung Wayang Tatah Sungging.

9) Brosur, sebagai media pemberi informasi mengenai segala sesuatu tentang Desa Kepuhsari sebagai Kampung Wayang Tatah Sungging.

10) Poster cetak atau $e$ poster juga berfungsi sebagai media pemberi informasi mengenai segala sesuatu tentang Desa Kepuhsari sebagai Kampung Wayang Tatah Sungging.

11) Web banner sabagai media virtual yang mampu merepresentasikan sekaligus mempromosikan eksistensi Kampung Wayang.

12) Media Sosial: instagram dan facebook sabagai media sosial yang mampu merepresentasikan sekaligus mempromosikan eksistensi Kampung Wayang.

13) Vidio dokumenter, sebagai media untuk mendokumentasikan proses tatah sungging maupun kondisi Desa Kepuhsari sebagai Destinasi Kampung Wayang sehingga selain sebagai media regenerasi dapat pula dijadikan sebagai media promosi (trailer).

14) Aplikasi mobile phone sebagai media tutorial untuk regenerasi pengrajin wayang kulit tatah sungging.

e. Monitoring, evaluation, and review.

Proses monitoring, evaluation, and review layak dilakukan ketika upaya penguatan branding Desa Kepuhsari sebagai Kampung Wayang direalisasikan. Apabila kelima tahap ini diterapkan maka harapannya penelitian ini mampu mendukung penguatan branding Desa Kepuhsari sebagai Destinasi Wisata Kampung Wayang hingga berdampak positif pada pemasukan ekonomi penduduk Desa Kepuhsari khususnya dan daerah Kabupaten Wonogiri, Jawa Tengah, umumnya.

\section{KESIMPULAN}

Beberapa strategi dalam upaya penguatan branding Desa Kepuhsari sebagai Destinasi Wisata Kampung Wayang Tatah Sungging agar keberadaannya tetap eksis dan makin dikenal oleh masyarakat luas baik dalam maupun luar negeri adalah sebagai berikut:

\section{Market investigation, analysis and strategic recommendations}

Pokdarwis Tetuko dan pemerintah setempat sudah melakukan analisis mengenai potensi Desa Kepuhsari yang kemudian dengan mengajak masyarakat lainnya, pengelola Pokdarwis Tetuko dan pemerintah setempat mulai merancang strategi untuk mengembangkan Desa Kepuhsari menjadi Kampung Wayang. Tahap berikutnya adalah mengupayakan agar potensi tersebut berdaya guna menguatkan branding Kampung Wayang. 


\section{Brand identity development}

Logo yang merupakan cerminan dari visi misi maka image sebagai Kampung Wayang mulai dicanangkan di Desa Kepuhsari. Terbentuknya logo merupakan tahap brand identity development yakni tahap menentukan identitas daerah yang bersifat intagible yang diperkenalkan kepada publik, untuk menggambarkan Desa Kepuhsari. Namun tagline dari Kampung Wayang belom diciptakan sehingga perlu didiskusikan lebih lanjut untuk menentuan tagline-nya.

\section{Brand launch and introduction, communicating the vision}

Setelah logo maupun tagline/slogan dibuat, tahap berikutnya adalah memperkenalkan brandmelalui berbagai media. Beberapa media yang sudah dibuat untuk mengomunikasikan keberadaan Desa Kepuhsari sebagai Destinasi Wisata Kampung Wayang adalah brosur, baliho, serta websitewww.wayangvillage.com dan www.astokenyo.com . Namun, sayangnya pengimplementasian brosur dan baliho tidak memvisualisasikan karakter tone and manner yang sama sebagai strategi komunikasi penciri dari branding Desa Kepuhsari sebagai Destinasi Wisata Kampung Wayang.

\section{Brand implementation}

Tahap selanjutnya, adalah brand implementation yang merupakan suatu usaha untuk mengintegrasikan semua pihak yang terlibat dalam pembentukan brand, sehingga destination branding sebagai Kampung Wayang dapat berhasil. Pengimplementasian logo, tagline serta identitas brand dapat dilakukan melalui beberapa media seperti: Stationary; Baliho/ billboard; Spanduk; Umbul-umbul; Traffic ad.; Name board/ neon box; Pembuatan buku ilustrasi; Pembuatan buku coffee table book; Brosur; Poster cetak atau e poster; Web banner; Media Sosial: instagram dan facebook; Vidio dokumenter; Aplikasi mobile phone (tutorial membuat wayang kulit tatah sungging)

\section{Monitoring, evaluation, and review.}

Proses monitoring, evaluation, and review layak dilakukan ketikan upaya penguatan branding Desa Kepuhsari sebagai Kampung Wayang direalisasikan.

Melalui upaya penguatan ini semoga penelitian ini mampu mendukung penguatan branding Desa Kepuhsari sebagai Destinasi Wisata Kampung Wayang hingga berdampak positif pada pemasukan ekonomi penduduk Desa Kepuhsari khususnya dan daerah Kabupaten Wonogiri, Jawa Tengah, umumnya.

\section{UCAPAN TERIMA KASIH}

Terima kasih diucapkan kepada Alloh SWT yang atas ridho-NYA membuat peneliti menyelesaikan penelitian dengan objek riset Desa Kepuhsari hingga mentekstualkannya sebagai pertanggungjawaban ilmiah terhadap laporan hasil penelitian. Kemudian terima kasih juga kami haturkan pada Universitas Sahid Jakarta yang telah memberikan kesempatan kepada peneliti untuk ikut berkontribusi dalam submit makalah pada jurnal nasioanal "Sinergi Ekonomi Kreatif dan Kepariwisataan di Era Digital" 2018. Tentunya juga kepada Universitas Sebelas Maret, universitas tercinta tempat peneliti mengabdi dan menimba ilmu yang telah berkontribusi memberikan ijin dalam realisasi penelitian dan penyusunan makalah ini. Tak lupa terima kasih yang tak terhingga kepada Mbak Retno Lawiyani dan Pak Sularjo, pejuang tangguh dan bersahaja yang konsisten melestarikan wayang kulit di Desa Kepuhsari atas kerjasama dan silaturahmi yang hangat selama 
penulis melakukan penelitian di sana. Semoga tulisan ini bermanfaat untuk menguatkan branding Desa Kepuhsari sebagai Destinasi Wisata Kampung Wayang Tatah Sungging di Kabupaten Wonogiri.

\section{DAFTAR PUSTAKA}

\section{Buku}

Black, J.A \& Dean J.C. (1992). Method and Issues in Social Research, terjemahan E. Koswara, PT. Eresco, Jakarta.

Bungin, B. (2003). Analisis Data Penelitian Kualitatif, Raja Grafindo Persada, Jakarta.

Creswell, J.W. (2009). Reseach Design: Pendekatan Kualitatif, Kuantitatif, dan Mixed, terjemahan Achmad Fawaid. (2014), Pustaka Pelajar, Yogyakarta.

Gobe, Marc. (2010). Emotional Branding: The New Paradigm for Connecting Brands to People, Allworth Press, New York.

Guba, E. (1990). The Paradigm Dialog, Sage Publication Inc., California.

Illiachenko, E.Y. (2005). Exploring Culture, History and Nature as Tourist Destination Branding Constructs: The Case of Pheriperal Region in Sweden, Nordic, Iceland.

Kaplanidou, K. (2007). Affective Event and Destination Image: Their Influence on Olympic Traveler's Behavioral Intention, Event Management.

Miles, M.B dan Huberman, A.M. (1984). Qualitative Data Analysis atau Analisis Data Kualitatif, terjemahan Tjetjep Rohendi Rohidi. (2009), Universitas Indonesia Press, Jakarta.

Moleong, L.J. (2011). Metodologi Penelitian Kualitatif, Remaja Rosdakarya, Bandung.

O'Brien, R. (1998). An Overview of The Methodological Approach of Action Research, Faculty of Information Studies, University of Toronto, Toronto.

Patton, M.Q. (2002). Qualitative Research \& Evaluation Methods, Sage Publications Inc., California.

Spillane, J. (1994). Pariwisata Indonesia (Siasat Ekonomi dan Rekayasa Kebudayaan), Kanisius, Yogyakarta.

\section{$\underline{\text { Jurnal }}$}

Is, P., Rini, A \& Marceilla, H. (2013). Pengaruh Destination Branding Terhadap Tourist Retention Pada Wisatawan Indonesia yang Berkunjung ke Thailand, Jurnal THE Anthology, Edisi I, Desember, ISSN 2337-6686.

Chanira, N., Suryadi \& Darsono, W. (2014). Designing Promotion Strategy of Malang Raya's Tourism Destination Branding through Audio Visual Media, Vol.2, No.2, April, E-ISSN 2338-1647.

Murfianti. (2010). Membangun City Branding Melalui Solo Batik Carnival. Jurnal Penelitian Seni dan Budaya. Volume 2 Nomor 1, Juni 20120. Pp.14-20.

Yuselg \& Putrikam, I. (2016). Kampung Wayang Sebagai Salah Satu Upaya Pemberdayaan Masyarakat di Desa Kepuhsari Kecamatan Manyaran Kabupaten Wonogiri, Journal UNY, Yogyakarta.

\section{Produk Hukum}


Undang-Undang Republik Indonesia Nomor 10 Tahun 2009 tentang Kepariwisataan.

Peraturan Daerah Kabupaten Wonogiri Nomor 9 Tahun 2011 tentang Rencana Tata Ruang Wilayah Kabupaten Wonogiri Tahun 2011-2031.

Peraturan Daerah Kabupaten Wonogiri Nomor 2 Tahun 2012 tentang Retribusi Jasa Usaha di Kabupaten Wonogiri.

Renstra Dinas Perindustrian Perdagangan Koperasi dan Usaha Mikro Kecil dan Menengah Kabupaten Wonogiri Tahun 2011-2015. 